\title{
Trial-and-error, Googling and talk: engineering students taking initiative out of class
}

Elaine Khoo and Bronwen Cowie

University of Waikato

\section{Introduction}

An assumption underpinning all of the chapters in this book is that informal learning processes are a fundamental aspect of many everyday activities. However, their relevance and contribution in more formal learning and educational settings has not always been recognised. Increased interest in informal learning can be linked with the impact of increases in the power and ubiquity of information and communication technologies (ICTs). These have increased and diversified the means individuals and groups have to access sources of information and support for learning. These offer formal learning agencies and processes the option of purposively leveraging resources such as Facebook, Twitter and the Internet alongside and in addition to providing formal supports for learning.

Increased interest in informal learning can also be linked with the current political imperative to foster student learning capacities and inclinations as part of preparing individuals who will prosper in the "knowledge society" (e.g., Bell et al. 2009). The European Union position paper The future of learning: preparing for change puts forward a vision of learning as a lifelong, lifewide process and notes that, "The overall vision that accompanies this [conceptualisation of learning] is that personalisation, collaboration and informalisation (informal learning) will be at the core of learning" (Redecker et al. 2011, p. 9). Building on this vision, Jackson (2014) asserts that "one of the most important things higher education can do to prepare adult learners for learning in the rest of their lives is to pay greater attention to the informal dimension of their learning lives while they are involved in formal study in higher education" (p. 1). Informal learning need not, and should not, be something that occurs after/outside of formal learning. Informal learning can usefully take place alongside and in combination with more formal learning activities as evidenced by current scholarship that calls for broader conceptualisations of learning (e.g., Barron 2006; Stocklmayer et al. 2010; and this book).

In the chapter we pay particular attention to what tertiary engineering students have to say about why they initiate informal learning activities to complement formal learning activities and the significance they place on these activities. We are particularly interested in the network of resources and supports that learners canand need-to develop to assist them to learn, and keep on learning, across the various contexts of their lives (Dierkling 2015). Specifically, we focus on the learning actions and strategies employed by engineering students outside of their scheduled formal learning activities (their lectures and labs) in learning how to use SolidWorks, a CAD software package. We conclude the chapter by speculating on the 
implications for teaching and learning when the formal-informal boundary blurs, and the nature and role of the "learning ecologies" (see Chapter XX by John Falk and Lynn Dierking, also Barron 2004) students develop in support of their own learning and personal development.

\section{Establishing a framework}

Formal learning, by design, is where learners engage with ideas and materials developed by a teacher as part of a programme of instruction. In tertiary settings formal learning tends to be associated with structured and didactic, teacher-led pedagogies aimed towards a particular end goal (Willems \& Bateman, 2013). Informal learning, on the other hand, is usually understood to be unstructured, selfdirected, emergent and linked with an individual's work-related, family or leisure activities (Dierking 2015; Halliday-Wynes \& Beddie, 2009). Typically, informal learning involves a combination of information seeking, observing, help seeking, asking questions, trial-and-error and so on (Siemens 2004). On the whole the initiative for informal learning starts with learners as they seek to deepen and extend their learning and understanding (Jackson 2013); it is the learner who takes responsibility for and ownership of the learning and its progress (Falk \& Dierking, 2010; Marques et al. 2013). This is congruent with understandings that in order to develop deep competences, learners must be motivated to do so otherwise they may simply cover content as a means to fulfill formal assessment criteria (Marques et al. 2013). Informal learning then happens in accordance with what is known variously as intrinsic motivation to learn (Boekaerts \& Minnaert, 1999), self-regulated learning (Zimmerman 2000), adaptive help seeking (Karabenick 2003), and selfdirected learning (Gillet et al. 2010). The question this chapter addresses is how students blur the line between formal and informal learning as part of self-directed learning. (Readers are also referred to Chapter XX, by Cathy Buntting, Alister Jones and Bronwen Cowie, for a discussion of incidental and intentional learning.)

\section{A learning ecologies approach to self-directed learning}

The rise of the Internet has made a significant impact on students' capacity for selfdirected or free-choice learning by making it easier for individuals to find and access "resources and activities that can support their learning on their own terms" (Barron 2006, p. 194). This has contributed to a rethinking of some of the assumptions about informal learning. In particular, attention has turned from an emphasis on the physical context of learning to the resources and strategies that individuals and groups can marshal to support their interest-driven learning (Falk \& Dierking 2010). The notion of a "personal learning ecology" is one way of making sense of the strategies and resources people use to progress their learning across time and settings. 
In this chapter, we define a learning ecology as encompassing the contexts, relationships, strategies and resources that an individual mobilises to achieve a personal learning goal. The notion of a learning ecology takes into account that the boundaries between contexts tend to be permeable, and that people draw on multiple relational and material resources to meet their current needs, no matter where they happen to be. Each and every context offers a "unique configuration of activities, material resources, relationships, and the interactions that emerge from them" (Barron 2006, p. 195). Both physical and virtual contexts can provide opportunities and supports for self-directed learning and the 2014 Horizon Report for Higher Education Preview (New Media Consortium, 2014) emphasises that social media tools can provide a useful, and in some cases preferred (Moll et al. 2015), way of accessing support from a networks of peers/ friends and experts.

Barron et al. (2006) highlight that more experienced students access and use a wider range and types of learning strategies and resources even when their access to physical and virtual resources is the same. They suggest differences might be due to variations in learner knowledge and interests, learner perceptions of the interdependencies between different resources, and learner resourcefulness (their capacity, inclination and persistence in identifying resources). Staron (2011) notes that in order to establish a learning ecology that is meaningful, authentic and supportive of their growth and personal well-being, learners have to have the courage to do what is most appropriate and useful in establishing and activating a network of supports. Learners therefore need to have the confidence, courage and capability to identify and pursue strategies that will support their learning and learning progress - and knowing how to create and sustain a learning ecology is an essential part of "knowing how to learn" in all the different contexts that comprise an individual's life (Jackson 2013, p.1).

\section{A holistic perspective for engineering education}

The Washington Accord (2013) is an international agreement among professional engineering institutions that confer accredited qualifications in professional engineering. It details the broad range of graduate attributes and professional competencies that today's engineering graduates need. Specifically, it states that the fundamental purpose of engineering education is to build each graduate's knowledge base and attributes so they can continue learning and develop the competencies required for independent practice beyond formal learning contexts. In this it recognises that graduates need to develop the capacity for self-directed lifelong learning for them to function effectively in an ever changing and increasingly complex world. In considering how to achieve these goals, Scott and Yates (2002) remark that it is important to "focus on the entire undergraduate experience rather than just what is taught" (p. 363). With this in mind, we examined the potential of an ecological approach for understanding engineering student experiences of learning CAD software across both formal and informal contexts. 


\section{A case study from engineering education}

In this chapter we draw on data from a Government-funded project Copy, cut and paste (CCP): how does this shape what we know? (Khoo et al. 2016) to report on the views of participating tertiary engineering students from the University of Waikato, New Zealand. The CCP study aimed to explore the development of software literacy in two tertiary teaching-learning contexts: mechanical engineering and media studies. We defined software literacy as involving expertise in using and critiquing the influence of discipline specific software in pursuit of particular learning and professional goals. Our premise was that developing the ability to problem solve and critique software is an essential proficiency in our software-saturated culture. For the purposes of this chapter, we report on the findings from the mechanical engineering case study. We were particularly interested in what enabled and constrained engineering students' learning to use a computer-aided design (CAD) software, SolidWorks. The use of CAD software is accepted practice in modern engineering and SolidWorks is used extensively in engineering industries across Australasia.

No entry-level familiarity with CAD or 3D drawing software is assumed at the onset of the degree programme, although students are expected to be familiar with the use of computers. In year 1 the students receive around six hours of formal instruction on SolidWorks. In year 2 students can choose to attend a series of three-hour supervised computer laboratory sessions where they complete tasks to develop their proficiency with SolidWorks. The course lecturer and tutors are available to assist students with any issues, difficulties and questions. Students can also use the computer labs at the university in their own time, and can opt to install SolidWorks on their personal computers and work through the same tasks at home. Each of the assigned tasks is assessed. As part of the year 2 course students are also required to collaborate on a group design project, which they present at a Faculty open day. The aim of the project is for students to develop and demonstrate their SolidWorkssupported design understanding and application.

Between their second and third year students spend 10 weeks on work placement in an engineering firm where they may be required to use SolidWorks or other similar CAD software. Third year course assessments require students to use SolidWorks in order to develop and build an artefact, such as a conveyor belt system, that incorporates the engineering design principles they have learned. These artefacts are exhibited and judged as part of a Faculty open day. In year 4 students are expected to use SolidWorks for individual projects.

Data were collected through observations of the year 2 students during the SolidWorks labs and interviews with the lecturer and tutors. We also surveyed students about the ways they learned SolidWorks in and out of labs and conducted a focus group with six volunteer students to elaborate on the survey results. 
Additionally, we conducted a focus group with seven volunteer year 3 students on if and how they had been able to use what they had learned about SolidWorks during their work placement. We wanted to see if and how students drew from similar strategies to those they had reported the year before. These focus groups took place soon after the students' work placement. We then observed the year 3 students working with SolidWorks as part of their coursework and conducted a focus group with seven students at the end of the year. A separate group of six elite year 4 students was interviewed. Each year our university is represented by a team of fourth and final year students in a prestigious international Formula SAE-A competition highly regarded by the industry. Each team must design, build and race a small high-performance race car. Those in the team are considered to have developed sophisticated software literacy skills.

Table 1 illustrates the data collection focus across the three years of study (Year 2 to 4). For this chapter, we are not presenting data from the year 1 students because the research focus for them was not on the development of their learning ecology.

Table 1: Description of the formal learning opportunities and data collection across the three years of study

\begin{tabular}{|c|c|c|c|}
\hline $\begin{array}{l}\text { Year } \\
\text { level }\end{array}$ & $\begin{array}{l}\text { Formal focus of SolidWorks } \\
\text { learning/use }\end{array}$ & $\begin{array}{l}\text { Data collection } \\
\text { procedure }\end{array}$ & $\begin{array}{l}\text { When } \\
\text { collected }\end{array}$ \\
\hline Year 1 & $\begin{array}{l}\text { Introduction to SolidWorks } \\
\text { including lab-based learning and } \\
\text { structured group project work }\end{array}$ & $\begin{array}{l}\text { No data were } \\
\text { collected }\end{array}$ & \\
\hline Year & $\begin{array}{l}\text { Lab-based learning followed by } \\
\text { structured group project work to } \\
\text { extend students' use of } \\
\text { SolidWorks in engineering design }\end{array}$ & $\begin{array}{l}\text { Student survey, } \\
\text { student focus } \\
\text { group, lecturer } \\
\text { interview, tutor } \\
\text { interview }\end{array}$ & $\begin{array}{l}\text { At the end of } \\
\text { the course }\end{array}$ \\
\hline & $\begin{array}{l}\text { Work placement-on the job use } \\
\text { of CAD }\end{array}$ & $\begin{array}{l}\text { Student focus } \\
\text { group }\end{array}$ & $\begin{array}{l}\text { Immediately } \\
\text { after the } \\
\text { completion of } \\
\text { work placement }\end{array}$ \\
\hline Year 3 & $\begin{array}{l}\text { Advanced individual lab-based } \\
\text { structured exercises and a real- } \\
\text { world group project using } \\
\text { SolidWorks }\end{array}$ & $\begin{array}{l}\text { Student focus } \\
\text { group, lecturer } \\
\text { interview }\end{array}$ & $\begin{array}{l}\text { At the end of } \\
\text { the design } \\
\text { course }\end{array}$ \\
\hline Year 4 & $\begin{array}{l}\text { Integrated use (all students) } \\
\text { Elite group of students design a } \\
\text { racing car for an international }\end{array}$ & $\begin{array}{l}\text { Student focus } \\
\text { group }\end{array}$ & $\begin{array}{l}\text { During the } \\
\text { design work }\end{array}$ \\
\hline
\end{tabular}




\begin{tabular}{|l|l|l|l|}
\hline competition & $\begin{array}{l}\text { comprising elite } \\
\text { student group }\end{array}$ & \\
\hline
\end{tabular}

Below, we report on the strategies and resources the Years 2 to 4 students described as supporting their use of and problem solving with SolidWorks.

\section{Changes in student learning preferences and ecologies}

Student commentary over the years of study indicated an increase in the sophistication of the kinds of pedagogical, technological and learning resources they accessed to productively learn to use and problem solve with SolidWorks. While the formal learning place was the university, the students' learning ecology encompassed a variety of material and relational resources and strategies. We begin by outlining the strategies the Year 2 students used.

\section{Year 2 students' learning preferences and ecologies}

Year 2 student survey data indicated that they used a variety strategies when learning to use SolidWorks (see Figure 1).

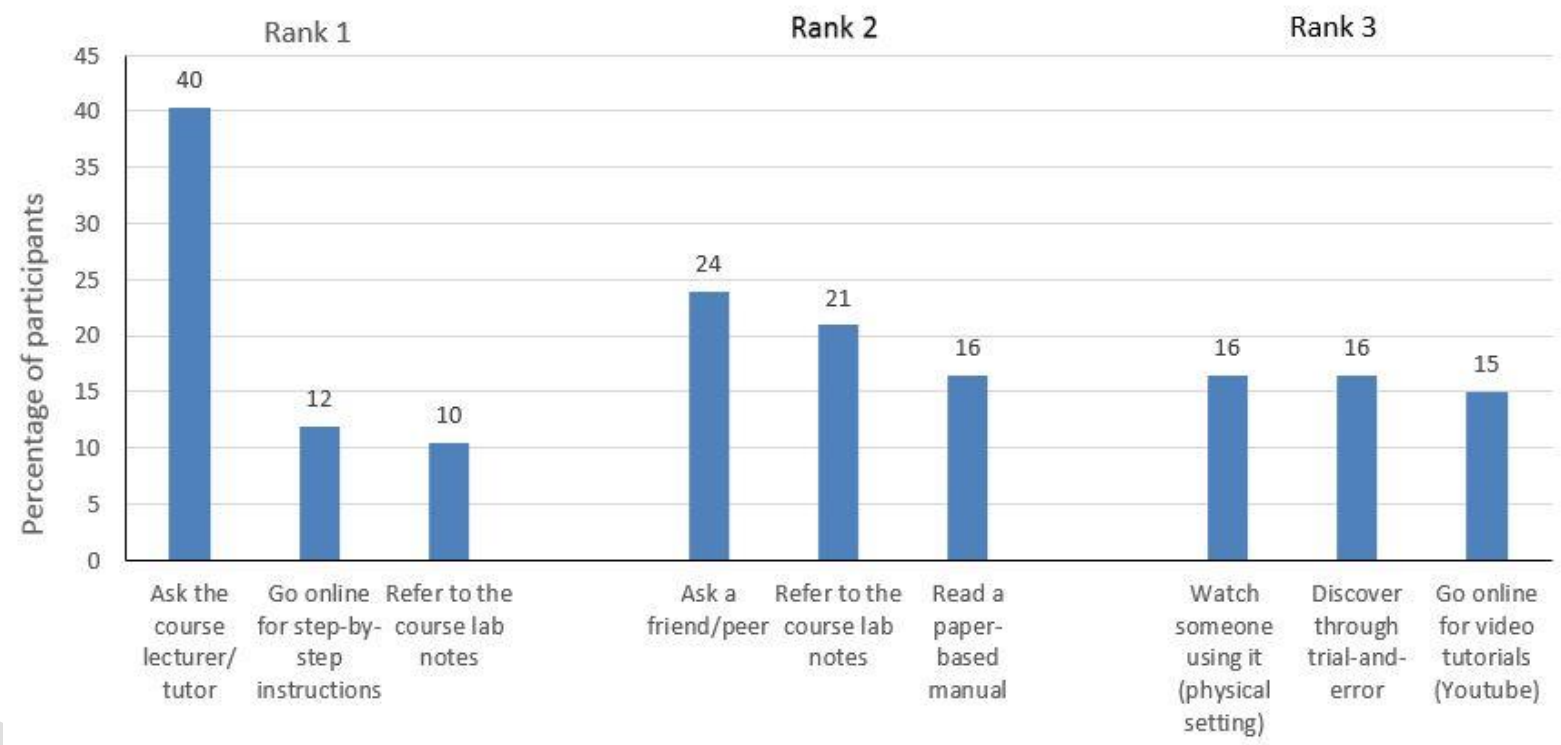

Figure 1. Rankings of strategies for learning SolidWorks $(n=67)$

Note: Rank 1 to Rank 3 denotes, in descending order, the usefulness of various strategies for learning SolidWorks as reported by students (taken from Khoo et al. 2014)

Almost $40 \%$ of students said their preferred problem solving approach would be to 'ask the lecturer for help'; for another $22 \%$ their first preference would be to 'go the Internet' or 'check their lab notes' for specific help. 'Lab notes' and/or the 
'SolidWorks (online) manual' was the second choice for $37 \%$ of the students; nearly a quarter $(24 \%)$ would 'ask a friend/peer' as their second choice. The strategies of 'watching someone using SolidWorks', 'trial-and-error' and 'Internet video tutorials' were the third most preferred choice for about a sixth of all participants.

The responses suggest that these Year 2 students tend to draw first on "official" and formally recognised authoritative sources of assistance. The lecturer and materials developed by the lecturer and/or support materials that were part of the software package were privileged. 'Asking peers' and 'trial-and-error' featured less.

Alongside, and somewhat in contradiction of these responses, three quarters (76\%) of the survey respondents reported installing SolidWorks on their own computer so they could use and practice using SolidWorks for their coursework in their own time. Just over a quarter $(27 \%)$ reported using SolidWorks outside of formal coursework for a range of recreational purposes. An example (from the open ended survey response) was:

I have many sketches which I have a hard time imagining in 3D therefore I use SolidWorks to give me a more detailed version of what I have imagined.

In focus groups, students reiterated they drew on a variety of resources and strategies to help them learn to use SolidWorks when working in a self-directed way. These included working through the tutorials embedded in the software, drawing on 'more expert' peers, discovering through trial-and-error, as well as using online materials such as YouTube instructional videos. A majority of students (84\%) reported they were comfortable in engaging with new technologies, hence their willingness to explore more informal ICT-supported forms of resources. These notably involved developing expertise in finding and identifying instructional material suited to 'their level'.

Students actively drew on help from more expert peers within the formal setting as exemplified in this comment:

I've been working next to a fourth year I'm friends with and he's looked at my work and gone, "Whoa, dude, hold on-let me show you how to do this" and he's stepped in and shown me a whole bunch of stuff.

The focus group students also recognised that learning to use SolidWorks required an investment of time for learning, stating:

'Cause there's so many tiny little individual parts about understanding SolidWorks that you get past a certain point and suddenly you don't know how to mirror a three-dimensional part, for example.

SolidWorks has a learning curve which can make things harder to do.

They signalled they were interested in working on real-life engineering design problems, first on their own and later with guidance from the lecturer. This 
discussion suggested that they were developing some confidence in their ability problem solve but that they recognised there were likely to be established procedures for dealing with the same problem:

I think what would be cool is if we had case studies or something; just some problems in class we could work through, the teacher could go through, like, "This is something that you may encounter while you're doing CAD, this is how we've gone about it, you could do it your way but this is the procedure we've used ...

Overall, there was a sense that the second year students prioritised lecturer prepared and/or authorised resources although they also sought out help from their peers and accessed online materials. Their survey data and comments indicated that they appreciated the need and value of a diversity of supports as part of a learning ecology focused on becoming more proficient in learning SolidWorks.

\section{Year 3 students' post work-placement and end of year reflections}

As a learning ecology has a contextual aspect we probed students' experiences of using SolidWorks while on work placement. We were interested in if and how they drew on the resources and strategies they had described to us as year 2 students. The year 3 focus group highlighted the range of strategies and people that they had to draw on as part of their learning ecology. These included an instructor-prepared reference sheet on key SolidWorks operations, seeking out help online, and asking workplace peers/colleagues:

I guess in the labs [at university] you could get help from the demonstrators but it's 8 am and they were taking a long time to come so I didn't, you know. Yeah, so I felt like the flip sheet [reference sheet], where it's there when you want it; like, going online is good but you waste a lot of time going online as well so that's why I tended to ask people at work. When I was doing the course at home I was always on the [SolidWorks help] forums and just general how-to's on the Internet.

This student further discriminated between strategies that were helpful when he was a novice and strategies after he had developed more independent and advanced troubleshooting skills.

If you were just beginning SolidWorks then the [online] tutorials that come with it [the software] is a good place to start. But when you get a bit more indepth it sort of loses its value. Yeah. Just asking people, especially if they know what they're doing, is the best way, I've found-that one-on-one sort of tuition.

After their placements, the students commented that it was not adequate to depend solely on university coursework to understand the various aspects and potential of the software in a workplace. They spoke of the value of practical and context- 
specific one-to-one assistance from more experienced industry experts when thrown into challenging real world contexts:

On my first day, I think, I was sat down and he was like, "Right, make this" and I made it and he was like, "That's totally wrong" and then spent like three days teaching me how to use it, just how he liked it.

Another student elaborated:

In my work placement I had a couple of people who knew how to do everything so I would ask them ... there was some stuff that they didn't know and there were some things that l'd learnt at Uni that they didn't know existed in SolidWorks so it's kind of interesting when you see people's overlap because they were self-taught as well. Yeah, they just always seemed to show me how to do it a lot easier than what I was doing it.

Threaded throughout these three comments is the idea that there are more and less efficient ways to get the job done. Subsequent group discussion indicated students were well aware of the need for persistence when working through a problem with SolidWorks:

I would say [I am] competent [in using SolidWorks] but I can be easily tripped up, and get stuck. I guess when I encounter a problem it does take me quite a while to get around it. If it's really pear-shaped or screwed up, you've got to sit there and nut it out.

The second focus group interview with the third year students occurred towards the end of the academic year. We were interested to see if there was any change in the ways students conceptualised and used a personal learning ecology to support advanced software use. Student commentary indicated that at this time students generally started troubleshooting by referring to Internet resources such as YouTube. They felt confident to do this because they had a knowledge base to draw from:

We had the base knowledge and it was generally pretty easy if you needed a little extra help. We had enough, like, knowledge to follow a tutorial [on YouTube] pretty easily.

Again, persistence to work through a challenge was seen as important, as raised by another student:

Yeah, if you do strike a problem generally you can just muscle through it, it may take a bit longer.

One student reflected on the strategies he had developed when highlighting the value of persistence and troubleshooting when working through advanced coursework:

From [first and second year] we pick up all the basic stuff and learn how to do it, but during that process we learn how to use the troubleshooting 
method and that's I think the most valuable thing that helped me later on ... I'm confident with even something I don't know, I know how to find it, how to learn it from online resources, then I can still make that happen [on

SolidWorks]. I think that's the most valuable thing, that even later when I go to my fourth year and do some more complicated thing, I know where to go, I [won't be stuck] and waiting for someone to help me. I can still go through my work and it may take a little bit of a long time but at the end of the day l'Il probably still pick it up.

The themes emerging from the year 3 interviews affirmed that students used and valued a variety of informal learning resources and strategies. Students accessed and used Internet resources, peers, and dogged persistence as part of their expanding learning ecology. A developing confidence in their own ability to troubleshoot underpinned the interplay of the learning resources and the strategies they drew from in order to be able to use SolidWorks to solve the more challenging problems associated with its use in real-world contexts. As they became more competent they relied more on their own resources and capacity to learn, and less on lecturer-prepared and commercial materials.

\section{Elite Year 4 students' learning preferences and ecologies}

The elite year 4 student group provided insights into the developmental trajectories that had contributed to their proficiency with SolidWorks. The trajectories they described involved an increase in understanding of the efficiency and sophistication of the design features that SolidWorks could be used to accomplish. They emphasised that "you've got to learn the foundations to do it effectively". One student explained:

Once someone teaches you the basics of sketches and you learn those things then you can start experimenting and troubleshooting and stuff and then using the different features and that gets you nice and efficient.

Another student elaborated, "There's often several ways of doing something and it's learning the most efficient way". Again, discussion focused on more than the need to produce a functional solution - the aim was an efficient design.

Students indicated that they continued to refer to the SolidWorks online manual, noting that it was comprehensive but not their first choice as an information source. The SolidWorks (in-built) tutorials were described as "good" for scoping out ideas although they were easy to get "lost" in. One student explained:

The [SolidWorks] tutorials are good for getting ideas when you start modelling [3D components].

The group endorsed the value of trial-and-error as a problem solving strategy: 
Students have definitely got to muck around through trial and error. They would really struggle if they just went in, did the stuff and then just went home. ... You just muck around and change some things and it works. So next time you go, "Well I did this last time and it worked".

Students used an Internet search (Google) to find answers to specific questions such as "Why won't my surfaces merge?", commenting that as Google searches generated a "million reasons" they needed to decide "do any of these apply to you?" They were clear that it was essential to critically engage with the various sources of help and support that were available.

Student representation of the learning process as a multifaceted activity was best reflected in the following extended comment by one of the students:

Probably one of the big things that's kind of cool is that we can take it [SolidWorks] home, use it on our personal computers at home, and come into the lab. You can work on assignments at home and play around on it at home. Another way that I picked up [ideas] was from working around people... working together and knowing how to do things better. You don't get that sort of support from the teachers. I guess if you go up and ask them, they probably will give you a hand, but most of my learning on SolidWorks has been done by working on it at home or playing around at home and learning from peers and also YouTube videos. If there's no one around and you can't do it, type it into Google, type it into YouTube, and hopefully you'll get something and if you don't then ask for some help.

A clear theme emerging from the year 4 focus group of students was that students had to want to "learn to drive the programme" and that they needed to invest personal time, beyond class time, to achieve this. Overall their view was, "You've got to be doing it independently as well, like the other guys have said. It's not something you can just pick up just from the class". Here we can see the extent to which this group of elite students was engaging in self-directed learning. The consensus was that over time they had taught themselves by doing tutorials, experimenting with the programme and watching how other people, including their tutors, went about completing design tasks. Their view appeared to be that in the long term they, and engineers, should be able to "teach" themselves:

You get to a level where you're capable-and I suppose that's just engineers as well-you're capable to teach yourself. You can use different resources just to teach yourself.

The significance of this understanding was confirmed by the lecturer who taught year 2 and 3 engineering design. He emphasised that students need to learn how to learn to problem solve. His expectation was that students would build on the more 
formal university-provided instruction and take up opportunities to learn SolidWorks through informal means.

\section{Discussion and Conclusion}

Current engineering professional standards emphasise the need for engineering graduates to develop capacity for self-initiated and self-directed learning (Jamieson \& Lohman 2009; National Academy of Engineering 2005; Washington Accord 2013). In this chapter, we have scoped the kinds of learning strategies and resources that engineering students used to supplement and extend their laboratory and lecture learning about using SolidWorks, a CAD tool. Students were clear that classroom time and materials designed to supplement the formal curriculum were useful but insufficient. The students we spoke with also emphasised the need for persistence in the face of challenge. They identified this and their own ability to be self-directed when working towards a solution as elements of their learning and learning to learn.

Early in their engineering programme students placed considerable value on formal supports but as time went by they made more use of help from peers, online resources (SolidWorks tutorials, Google, YouTube), expert others and trial-anderror. The fourth year students indicated they had developed a sophisticated learning ecology that included the capacity to critically gauge which resources were appropriate to their learning level and the task design aims. In contexts comprising the university, workplace and home, our participants described learning ecologies consisting of multiple relational and material resources-knowledgeable peers and workplace colleagues and Internet-based resources of various kinds.

For us, students' drawing on help from peers and online resources across formal and informal settings raises questions about the distinction between the two. Although these findings focus on engineering students' learning of a disciplinary specific software package, some key ideas can be distilled as implications for other disciplines and tertiary institutions as a whole. For example, we agree with Jackson (2013) and Redecker et al. (2011) that a learner's ability to create their own ecology for learning and development is a crucial capability in today's complex and dynamic world. This means lecturers have an obligation to help students become aware of the need to develop a repertoire of learning strategies and resources.

Concomitantly, they have an obligation to provide students with opportunities to develop this repertoire. As part of this, they need to foster students' confidence, courage and resilience to learn —and to learn how to learn—new ideas. These are an essential element of a learning ecology (Staron 2011). For many lecturers in tertiary education fostering student learning ecologies will involve a shift from a lecturer as a dispenser of knowledge to someone who more proactively supports students to take on more independent and critical roles in their own learning -and this has implications beyond individual lecturer change. 
Institutions need to consider how they might assist students to develop productive lifelong learning capacities for the $21^{\text {st }}$ Century work and leisure environment. We wonder if, how and to what effect the notion of a learning ecology might be incorporated into institutional graduate profiles as a tool for assisting lecturers and students to develop the network of learning strategies and supports (both formal and informal) essential to individuals being able to learn lifelong and lifewide. As tertiary institutions increasingly move to exploit the teaching and learning potential of elearning and social media platforms, we need to be aware that new and different kinds of learning and learning ecologies will become possible. This offers an exciting space for further research, policy and practice development.

\section{Acknowledgements}

We gratefully acknowledge funding support from the Teaching and Learning Research Initiative, Ministry of Education, New Zealand.

\section{References}

Barron, B. (2004). Learning ecologies for technological fluency: gender and experience differences. Journal of Educational Computing Research, 31(1), $1-36$.

Barron, B. (2006). Interest and self-sustained learning as catalysts of development: a learning ecology perspective. Human Development, 49,193-224.

Bell, P., Shouse, A., Lewenstein, B., \& Feder, M. (2009). Learning science in places and pursuits. Washington, DC: National Research Archives.

Boekaerts, M., \& Minnaert, A. (1999). Self-regulation with respect to informal learning. International journal of educational research, 31(6), 533-544.

Dierking, L. D. (2015). Learning science in informal contexts. In R. Gunstone (Ed.), Encyclopedia of Science Education (pp. 607-615). Netherlands: Springer.

Falk, J. H., \& Dierking, L. D. (2010). The 95\% solution: school is not where most Americans learn most of their science. American Scientist, 98, 486-493.

Gillet, D., Law, E.L.C., Chatterjee, A. (2010). Personal learning environments in a global higher engineering education Web 2.0 realm. In: 1st IEEE Engineering Education Conference (EDUCON). Madrid, Spain. Retrieved from http://www.role-project.eu/wp-content/uploadsrole/2010/01/educon dg final free.pdf

Halliday-Wynes, S., \& Beddie, F. (2009). Informal learning. At a glance. National Centre for Vocational Education Research Australia. Retrieved from http://files.eric.ed.gov/fulltext/ED507131.pdf

Jackson, N. J. (2013). The Concept of Learning Ecologies. In N. J. Jackson and B. C. Cooper (Eds.), Lifewide learning, education and personal development. Ebook available from www.lifewideebook.co.uk

Jackson, N. (2014). Ecology of lifewide learning \& personal development. Keynote presentation at the University of Brighton's Annual Learning and Teaching Conference. Retrieved from 
http://about.brighton.ac.uk/clt/files/3014/0422/8832/Ecology of Learning an

d Development Handout.pdf

Jamieson, L. H., \& Lohmann, J. R. (2009). Creating a culture for scholarly and systematic innovation in engineering education: ensuring US engineering has the right people with the right talent for a global society. American Society of Engineering Educators (ASEE), 30(17), 246-251.

Karabenick, S. A. (2003). Seeking help in large college classes: a person-centered approach. Contemporary Educational Psychology, 28(1), 37-58.

Keefer, J. A., \& Karabenick, S. A. (1998). Help seeking in the information age. In S. Karabenick (Ed.), Strategic help seeking: implications for learning and teaching (pp. 219-250). Mahwah, NJ: Lawrence Erlbaum.

Khoo, E., Hight, C., Torrens, R., \& Cowie, B. (2016). Copy, cut and Paste: How does this shape what we know? Final report. Wellington: Teaching and Learning Research Initiative. Available at http://www.tlri.org.nz/tlri-research/researchcompleted/post-school-sector/copy-cut-and-paste-how-does-shape-what-weknow

Khoo, E., Hight, C., Torrens, R., \& Duke, M. (2014). "It runs slow and crashes often": exploring engineering students' software literacy of a computer-aided design software. In A. Bainbridge-Smith, Z. T. Qi, \& G. S. Gupta (Eds.), Proceedings of the $25^{\text {th }}$ Annual Conference of the Australasian Association for Engineering Education (AAEE2014). Palmerston North, New Zealand: School of Engineering \& Advanced Technology, Massey University. Marques, M., Viegas, M., Alves, G, Zangrando, V., Galanis, N., Brouns, F., Waszkiewicz, E., \& García-Peñalvo, F. (2013). Managing informal learning in higher education contexts: the learners' perspective. In ICBL2013: International Conference on Interactive Computer-Aided Blended Learning, November 06-08, 2013. Florianópolis, Brasil. Retrieved from http://dspace.learningnetworks.org/bitstream/1820/5150/1/ICBL 2013 final 78.pdf

Moll, R., Nielsen, W., \& Linder, C. (2015). Physics students' social media learning behaviours and connectedness. Paper presented at NARST, Chicago. Retrieved from http://wordpress.viu.ca/mollr/files/2015/04/NARST-2015paper-submitted.pdf

New Media Consortium. (2014). NMC horizon report: 2014 higher education preview. Austin, TX: Author.

Redecker, C., Leis, M.,Leendertse, M., Punie, Y., Gijsbers, G., Kirschner, P., Stoyanov, S., \& Hoogveld, B. (2011). The future of learning: preparing for change. Luxembourg: JRC European Union. Retrieved from http://ftp.jrc.es/EURdoc/JRC66836.pdf

Scott, G., \& Yates, K. W. (2002). Using successful graduates to improve the quality of undergraduate engineering programmes. European Journal of Engineering Education, 27(4), 363-378. 
Brown, J. S. (2000). Growing up: Digital: How the web changes work, education, and the ways people learn. Change: The Magazine of Higher Learning, 32(2), 11-20.

Siemens, G. (2004). Categories of e-learning. Retrieved from http://www.elearnspace.org/Articles/elearningcategories.htm

Staron, M. (2011). Connecting and integrating life based and lifewide learning. In N. J. Jackson (Ed.), Learning for a complex world: lifewide concept of learning (pp. 137-159). Bloomington, IN: AuthorHouse.

Stocklmayer, S., Rennie, L., \& Gilbert, J. (2010). The roles of the formal and informal sectors in the provision of effective science education. Studies in Science Education, 46(1), 1-44.

Washington Accord. (2013). Graduate attributes and professional competencies. Retrieved from http://www.ieagreements.org

Willems, J. \& Bateman, D. (2013). Facing up to it: blending formal and informal learning opportunities in higher education contexts. In G. Trentin \& M. Repetto (Eds.), Using network and mobile technology to bridge formal and informal learning (pp. 93-118). Cambridge, England: Woodhead.

Zimmerman, B. J. (2000). Attainment of self-regulation: a social cognitive perspective. In M. Boekaerts, P. Pintrich, \& M. Zeidner (Eds.), Selfregulation: theory, research, and applications (pp. 13-39). Orlando, FL: Academic 